\title{
EFFECT OF SOME MEDICINAL PLANT WASTES ON RABBIT PERFORMANCE, DIGESTIBILITY AND NITROGEN BALANCE
}

\author{
K.M. Abdel-Rahman ${ }^{1}$; B.M. Ahmed ${ }^{1}$; M.S. Abousekken² ${ }^{2}$ U.A. Nayel ${ }^{1}$ and A.M. Musa ${ }^{2}$ \\ ${ }^{1}$ Department of Animal Production, Faculty of Agriculture, Minoufiya University, Minoufiya, Egypt. \\ ${ }^{2}$ Environmental Studies and Research Institute, Sadat City University, Minoufiya, Egypt.
}

(Received 26/6/2018, accepted $24 / 7 / 2018$ )

\section{SUMMARY}

\begin{abstract}
A total number of 42 growing crossbred rabbits of both sexes at 6 weeks of age (with an average body weight $750 \pm 50 \mathrm{~g}$ ) were randomly divided into 7 equal groups to evaluate the growth performance as affected by medicinal plant wastes. Rabbits were fed control (AH) diet and 6 experimental diets contained the wastes of moringa (M), cassava (C) and tartofa $(\mathrm{T})$ hay meal at two levels $(10$ and $15 \%)$ for each for a period of 8 weeks. Digestibility of nutrients and nitrogen balance were also evaluated. The results obtained showed that chemical composition of moringa hay meal (M), cassava hay meal (C), tartofa hay meal (T) and alfalfa hay (AH) were; DM 93, 91, 87 and 92\% for M, C, T and AH, respectively. The corresponding values of OM were $89,90.8,91.25$ and $84.42 \%$. The hays of the medicinal plant wastes had less CP than AH being $7.63,7.7,6.75$ vs. $17.51 \%$. Moringa hay contains more CF (20.75\%) than both cassava $(10.18 \%)$ and tartofa $(7.15 \%)$; alfalfa hay, however, contains the highest value of CF $(24.1 \%)$. The proximate analysis of the experimental diets showed iso-caloric and almost iso-nitrogenous values of these diets. No significant differences on average body weight. Total body weight gain was $1505,1665,1536,1703,1552,542$ and 1525 for the same respective groups; average daily gain followed the same pattern with average values of 26.9, 29.7, 27.4, 30.4, 27.7, 27.5 and 27.2g/d. Total feed per rabbit during the 8-week experimental period was 5.77, 6.31, 6.51, 6.16, 5.99, 5.77 and $5.75 \mathrm{~kg}$ for $\mathrm{AH}, \mathrm{M} 10, \mathrm{M} 15, \mathrm{C} 10, \mathrm{C} 15, \mathrm{~T} 10$ and T15, respectively. Feed conversion (kg feed/kg gain) during the period of the study was not affected by the dietary treatments. Feed conversion ratio was 3.83, 3.79, 4.24, 3.61, 3.86, 3.75 and 3.77 for AH, M10, M15, C10, C15, T10 and T15, respectively. The highest PI value was significantly $(\mathrm{P}<0.05)$ recorded with group fed C10 diet (68.59\%) followed by those T10 (66.30\%), M10 (62.51\%), C15 (61.14\%), T15 (59.41\%); and $\mathrm{AH}(58.31 \%)$ the least was recorded for M15 (55.21\%). Using hay of such medicinal plants diets causes improvement in the digestion coefficients and feeding values than alfalfa hay. Replacing alfalfa hay with either one of the medicinal plant wastes increased nitrogen balance and biological values. Differences were significant $(\mathrm{P}<0.05)$.
\end{abstract}

Keywords: Medicinal plant wastes, rabbits, digestibility and $N$ balance.

\section{INTRODUCTION}

Many developing countries import most of the animal and poultry feeds, which is not economically feasible; therefore, more attention was given to agro-industrial by-products. Non-traditional feed sources such as crop residues and agro-industrial by-products must be searched in order to decrease the relay on traditional sources, to fill the gap and decrease feeding costs (Zaza, 2005). Incorporation of cheap untraditional feedstuffs such as the agro-industrial by-products in animal diets (Shqueir and Qwasmi, 1994) may participate in solving the problem and decrease the cost of feeding (Al-Shanti, 2003). In Egypt, medicinal and aromatic plants are cultivated in large areas (about 48 thousands feddan) producing about 2.4 million tons of plant by-products annually (Agriculturale Economics, 2006), Approximately, two thirds of these residues are burned or wasted, and hence lead to 
environmental pollution and health hazards, therefore, using these residues for animal or poultry feeding is a method to control environmental pollution (Zaza, 2004).

Attempt to use natural materials such as medicinal plants could be widely accepted as feed additives. However, little information is available about using medicinal plant by-products in rabbit diets. Rabbits are characterized by many advantages that make them suitable animal, it could be bred to minimize the gap between the demand and available of animal protein (FAO, 1987; Galal and Khalil, 1994 and Daadar and Seleem, 1999). Recently, several efforts were carried out to use local agricultural by-products in animal feeding due to their participation as part in the solution of feed shortage problems and dramatic increases in prices of animal feed ingredients (Abd EI-Baki et al., 2001). The natural materials as alternative growth promoters such as medicinal plants are widely accepted (Noland 1965 and Aboul-Fotouh et al., 1999). Also, some studies indicated that such plants have favorable effects on live weight gain and feed efficiency with broiler chicken (Fritz et al., 1992 and Fritz et al., 1993) and with cows (Singh and Taparia, 1992).

Therefore, the present study aimed to investigate the effective partial substitution of alfalfa hay by different levels of moringa, cassava and tartofa hay meals in growing rabbit diets, on growth performance, nutrients digestibility, feeding values and nitrogen balance.

\section{MATERIALS AND METHODS}

The present study was carried out at Rabbit Research Unit, Poultry Research Station, belonging to Environmental Studies and Research Institute, Sadat City University, Sadat City, Minoufiya Governorate, Egypt, during winter 2016. A total number of 42 growing crossbred rabbits of both sexes at 6 weeks of age (with an average body weight $750 \pm 50 \mathrm{~g}$ ) were randomly divided into 7 equal groups, 6 for each. Rabbits were fed control diet and 6 experimental diets contained the moringa (Moringa oleifera) hay meal (M), cassava (Manihot esculenta) hay meal (C) and tartofa (Helianthus tuberosus) at two levels (10 and 15\%) to replace equal amounts of alfalfa hay. Diets were manufactured in pellets shape at El-Keram diets Factory-Sadat City. The experimental diets and fresh water were available all the time during the experimental period. Rabbits were individually weighed weekly. The digestibility trial of the present study took place at the end of the experiment (at week 9), three animals from each experimental treatment were chosen randomly and housed individually in metabolism cages and were given ad libitum the experimental diet for one week as an adaptation period, after which the total fecal excretions were collected daily in plastic bags for 5 days and stored at $-10^{\circ} \mathrm{C}$ for nitrogen balance and urinary excretions during the same collection period were also collected daily in plastic bottles and kept frozen up to the chemical analyses. The complete chemical compositions of feed, remainder feed (if any) and feces were determined according to the AOAC (1990). Nitrogen in urine samples was determined by the Micro-Kjeldahl method. Feed intakes were determined daily by subtracting the residual feeds from the daily allowance. For digestibility trial, data on nutrients intake and output, coefficients of digestion and feeding value [in terms of total digestible nutrients (TDN), digestible crude protein (DCP) and digestible energy (DE)] were recorded. Data of nitrogen intake, fecal and urinary nitrogen, nitrogen retention and biological value were recorded as parameters of the nitrogen balance. Digestible energy (DE) values were calculated according to Cheeke (1987). The feed intake and total collection of feces and urine were conducted to determine the digestion coefficient of nutrients and feeding values of the experimental diets. Chemical analysis of diets and feces were carried out according to AOAC (1990).

The chemical composition and feeding values of the experimental diets are calculated and presented in Tables $(1 \& 2)$. The formulations of the experimental diets were done according to the nutrient requirements of growing rabbits (NRC, 1977). Growth performance index (PI) was calculated according to the equation described by North (1981).

Data were statistically analyzed according to SPSS (1997). The statistical model used was the oneway analysis of variance as follows:

$Y_{i j}=u+A_{i}+e_{i j}$ Where: $Y_{i j}=$ the observation on the $i^{\text {th }}$ rabbit, $u=$ overall mean, $A_{i}=$ the effect of the $\mathrm{i}^{\text {th }}$ diet $(\mathrm{i}=1,2, \ldots 7), \mathrm{e}_{\mathrm{ij}}=$ experimental random error. The significant differences between means were tested using Duncan's multiple range test (Duncan, 1955). 
Egyptian J. Nutrition and Feeds (2018)

Table (1): Composition of the experimental diets.*

\begin{tabular}{lccccccc}
\hline \multirow{2}{*}{ Ingredient } & \multicolumn{7}{c}{ Treatment*** } \\
\cline { 2 - 7 } & $\mathrm{AH}$ & $\mathrm{M} 10$ & $\mathrm{M} 15$ & $\mathrm{C} 10$ & $\mathrm{C} 15$ & $\mathrm{~T} 10$ & $\mathrm{~T} 15$ \\
\hline Alfalfa hay de. 17\% & 41 & 31 & 26 & 31 & 26 & 31 & 26 \\
Moringa hay meal (M) & - & 10 & 15 & - & - & - & - \\
Cassava hay meal (C) & - & - & - & 10 & 15 & - & - \\
Tartofa hay meal(T) & - & - & - & - & - & 10 & 15 \\
Yellow corn & 27 & 27 & 27 & 27 & 27 & 27 & 27 \\
Soybean meal (44\%CP) & 18 & 18 & 18 & 18 & 18 & 18 & 18 \\
Wheat bran & 7.8 & 7.8 & 7.8 & 7.8 & 7.8 & 7.8 & 7.8 \\
Molasses & 3 & 3 & 3 & 3 & 3 & 3 & 3 \\
Calcium di phosphate & 2.2 & 2.2 & 2.2 & 2.2 & 2.2 & 2.2 & 2.2 \\
DL methionine & 0.4 & 0.4 & 0.4 & 0.4 & 0.4 & 0.4 & 0.4 \\
Salt (NaCl) & 0.3 & 0.3 & 0.3 & 0.3 & 0.3 & 0.3 & 0.3 \\
Vit. \& Min. premix $* *$ & 0.3 & 0.3 & 0.3 & 0.3 & 0.3 & 0.3 & 0.3 \\
Total & 100 & 100 & 100 & 100 & 100 & 100 & 100 \\
\hline
\end{tabular}

* Calculated according to NRC (1977).

** Each one $\mathrm{kg}$ of vitamin \& mineral mixture contains: Vit. A $4000000 \mathrm{IU}$; Vit $D_{3} 50000 I U$; Vit E $16.7 g$; Vit $K_{3}$, $0.67 g$; Vit. $B_{1} 67 g$; Vit $B_{2} 2.00 g$; Vit. $B_{6} 0.67 g$; Vit $B_{12} 3.33 \mathrm{mg}$; Cholin chloride $400 g$.; Biotin $0.07 \mathrm{~g}$;Niacin $16.7 \mathrm{~g}$.; pantothenic acid 6.7g; Folic acid 1.7g;; Copper 1.7g; Iron 25.00g; Manganese 10.00g; Iodine 0.25g; Selenium 33.3g; Zinc 23.3g and Magnesium 133.3g.

*** M, Moringa; $C$, Cassava; $T$, Tartofa at both 10 or $15 \%$ replacements.

Table (2): Calculated chemical analysis and feeding value of the experimental diets.

\begin{tabular}{lccccccc}
\hline \multirow{2}{*}{ Item** } & \multicolumn{7}{c}{ Experimental diet* } \\
\cline { 2 - 8 } & Control(AH) & M10 & M15 & C10 & C15 & T10 & T15 \\
\hline CP, \% & 17.8 & 17 & 16.5 & 17 & 16.5 & 16.8 & 16.3 \\
CF, \% & 11 & 11.5 & 12 & 10 & 10.5 & 10.1 & 10.25 \\
EE, $\%$ & 3 & 3.1 & 3.21 & 3.2 & 3.3 & 3.15 & 3.25 \\
TDN,\% & 60 & 58 & 55 & 58 & 55 & 57 & 53 \\
\hline
\end{tabular}

*M, Moringa; $C$, Cassava; $T$, Tartofa at both 10 or $15 \%$ replacements.

** CP, crude protein; $C F$, crude fiber; EE, ether extract and TDN, total digestible nutrients.

\section{RESULTS AND DISCUSSION}

The chemical composition of moringa hay meal (M), cassava hay meal (C), tartofa hay meal (T) and alfalfa hay (AH) are presented in Table (3). DM was 93, 91, 87 and 92\% for M, C, T and $\mathrm{AH}$, respectively. The corresponding values of OM were $89,90.8,91.25$ and $84.42 \%$. The hays of the medicinal plant wastes had less $\mathrm{CP}$ than $\mathrm{AH}$ being $7.63,7.7,6.75$ vs. $17.51 \%$. Moringa hay contains more CF $(20.75 \%)$ than both cassava $(10.18 \%)$ and tartofa $(7.15 \%)$; alfalfa hay, however, contains the highest value of CF (24.1\%). The used wastes had more EE (being $7.33 \%$ for moringa, $7.65 \%$ for cassava and $8.15 \%$ for tartofa) than alfalfa hay (2.5\%). Regarding NFE, the medicinal wastes contained more than alfalfa hay by about $150 \%$; values were $53.29,65.27,69.2 \%$ for $\mathrm{M}, \mathrm{C}$ and $\mathrm{T}$ comparing to $40.31 \%$ for $\mathrm{AH}$. The gross energy was calculated and presented also in Table (3); it was 3568, 3626, 3433 and $3743 \mathrm{kcal} / \mathrm{kg}$ DM for M, C, T and AH, respectively. Ash content was 11, 9.2, 8.75 and $15.58 \%$ for the same respective order. Musa (2008) reported similar values for parsley and basil wastes. It was suggested that medicinal plant wastes could partially replace clover hay in the diets of growing rabbit (Radwan and Khalil, 2002; Awad, 2003 and El-Manylawi et al., 2003 and 2005). Ogbe and Affiku (2011) determined the proximate analysis of moringa leaf and found that results revealed the presence of 
high crude protein $(17.01 \% \pm 0.1)$ and carbohydrate $(63.11 \% \pm 0.09)$. The leaves also contained appreciable amounts of crude fiber $(7.09 \% \pm 0.11)$, ash $(7.93 \% \pm 0.12)$, crude fat $(2.11 \% \pm 0.11)$ and fatty acid $(1.69 \% \pm 0.09)$. They concluded that Moringa oleifera leaves could be utilized as a source of feed supplement to improve growth performance and health status of poultry. Cieślik et al. (2011) stated that Jerusalem artichoke, tartofa (Helianthus tuberosus L.) had high protein content, including essential amino acids. The proximate analysis of the experimental diets showed iso-caloric and almost isonitrogenous values of these diets (Table 4). The calculated gross energy ( $\mathrm{kcal} / \mathrm{kg} \mathrm{DM})$ of the experimental diets was 3880, 3842, 3838, 3830, 3863, 3845 and 3811 for AH, M10, M15, C10, C15, T10 and T15, respectively. Results showed that CP content of the experimental diets was 18.34, 17.92, 17.44, 17.74, 17.3, 17.56 and 16.95\% for AH, M10, M15, C10, C15, T10 and T15, respectively. Differences, however, did not reach a significant level; therefore, diets were considered iso-nitrogenous. Abousekken et al. (2007) reported nearly similar results.

Table (3): Chemical composition of the wastes used in the present study.*

\begin{tabular}{lcccccccc}
\hline Waste & \multicolumn{7}{c}{$\%$} & \multirow{2}{*}{ Gross Energy Kcal/kg } \\
\cline { 2 - 7 } & DM & OM & CP & CF & EE & NFE & Ash & 3568 \\
Moringa & 93 & 89 & 7.63 & 20.75 & 7.33 & 53.29 & 11 & 3626 \\
Cassava & 91 & 90.8 & 7.7 & 10.18 & 7.65 & 65.27 & 9.2 & 3433 \\
Tartofa & 87 & 91.25 & 6.75 & 7.15 & 8.15 & 69.2 & 8.75 & 3743 \\
Alfalfa & 92 & 84.42 & 17.51 & 24.10 & 2.50 & 40.31 & 15.58 & \\
\hline
\end{tabular}

*Determined values.

DM, dry matter; OM, organic matter; $C P$, crude protein; $C F$, crude fiber; EE, ether extract and NFE, nitrogen free extract.

Table (4): Chemical composition of the experimental diets used in the present study.

\begin{tabular}{lccccccc}
\hline \multirow{2}{*}{ Item } & \multicolumn{7}{c}{ Treatments } \\
\cline { 2 - 8 } & $\mathrm{AH}$ & $\mathrm{M} 10$ & $\mathrm{M} 15$ & $\mathrm{C} 10$ & $\mathrm{C} 15$ & $\mathrm{~T} 10$ & $\mathrm{~T} 15$ \\
\hline DM \% & 91.15 & 91.75 & 91.25 & 91.5 & 90.3 & 91.6 & 90.85 \\
\multicolumn{2}{l}{ On DM basis $(\%):$} & & & & & & \\
OM & 88.75 & 88.6 & 89 & 88.55 & 88.85 & 88.9 & 88.7 \\
$\mathrm{CP}$ & 18.34 & 17.92 & 17.44 & 17.74 & 17.3 & 17.56 & 16.95 \\
$\mathrm{CF}$ & 11.25 & 11.85 & 12.35 & 9.75 & 9.6 & 10.05 & 10.2 \\
EE & 3.2 & 2.65 & 2.4 & 2.8 & 3.4 & 2.87 & 2.55 \\
NFE & 55.96 & 56.18 & 56.81 & 58.26 & 58.55 & 58.42 & 59 \\
Ash & 11.25 & 11.4 & 11 & 11.45 & 11.15 & 11.1 & 11.3 \\
GE** & 3880 & 3842 & 3838 & 3830 & 3863 & 3845 & 3811 \\
\hline
\end{tabular}

*M, Moringa; C, Cassava; T, Tartofa at both levels 10 and $15 \%$ and AH, alfalfa hay (control).

** GE, gross energy kcal/kg DM, calculated.

Results in Table (5) present the change in body weight of growing rabbits as affected by the dietary treatments. The initial body weight was almost equal in all groups with average of $770 \mathrm{~g}$ (ranging from 704 to $858 \mathrm{~g}$ ). No significant differences regarding average body weight indicting that no adverse effect of any dietary treatment on the growth of the experimental animals. Rabbits reached the final body weight at the end of the experimental period without any significant changes; final body weight was 2233, 2369, 2341, 2476, 2360, 2400 and 2240g for AH, M10, M15, C10, C15, T10 and T15, respectively. The total body weight gain was $1505,1665,1536,1703,1552,1542$ and 1525 for the same respective groups; differences were not significant. The average daily gain (ADG) followed the same pattern of total gain with average values of 26.9, 29.7, 27.4, 30.4, 27.7, 27.5 and 27.2g/d. 
Egyptian J. Nutrition and Feeds (2018)

Table (5): Growth performance of rabbits as affected by dietary treatments (Means \pm SE).

\begin{tabular}{|c|c|c|c|c|c|c|c|c|}
\hline \multirow{2}{*}{ Item } & \multirow{2}{*}{$\mathrm{AH}$} & \multicolumn{2}{|c|}{$\mathrm{M}$} & \multicolumn{2}{|c|}{$\mathrm{C}$} & \multicolumn{2}{|c|}{$\mathrm{T}$} & \multirow{2}{*}{ Sig. } \\
\hline & & $10 \%$ & $15 \%$ & $10 \%$ & $15 \%$ & $10 \%$ & $15 \%$ & \\
\hline \multirow[t]{3}{*}{ Initial weight(g) } & 729 & 704 & 804 & 772 & 808 & 858 & 716 & \multirow{3}{*}{ NS } \\
\hline & \pm & \pm & \pm & \pm & \pm & \pm & \pm & \\
\hline & 60 & 56 & 69 & 65 & 51 & 41 & 61 & \\
\hline Final & 2233 & 2369 & 2341 & 2476 & 2360 & 2400 & 2240 & \multirow{3}{*}{ NS } \\
\hline \multirow{2}{*}{ Weight (g) } & \pm & \pm & \pm & \pm & \pm & \pm & \pm & \\
\hline & 55 & 78 & 53 & 110 & 56 & 98 & 77 & \\
\hline \multirow[t]{3}{*}{ Total gain $(\mathrm{g})$} & 1505 & 1665 & 1536 & 1703 & 1552 & 1542 & 1525 & \multirow{3}{*}{ NS } \\
\hline & \pm & \pm & \pm & \pm & \pm & \pm & \pm & \\
\hline & $\overline{70}$ & $\overline{45}$ & 25 & 103 & 56 & 55 & 69 & \\
\hline $\mathrm{ADG}$ & 26.9 & 29.7 & 27.4 & 30.4 & 27.7 & 27.5 & 27.2 & \multirow{3}{*}{ NS } \\
\hline \multirow[t]{2}{*}{$(\mathrm{g} / \mathrm{d})$} & \pm & \pm & \pm & \pm & \pm & \pm & \pm & \\
\hline & 1.25 & 0.81 & 0.45 & 1.84 & 1.01 & 0.99 & 1.24 & \\
\hline \multirow[t]{3}{*}{ Total FC (kg) } & 5.77 & 6.31 & 6.51 & 6.16 & 5.99 & 5.77 & 5.75 & \multirow{3}{*}{ NS } \\
\hline & \pm & \pm & \pm & \pm & \pm & \pm & \pm & \\
\hline & 0.7 & 0.9 & 0.5 & 0.5 & 0.9 & 0.8 & 0.8 & \\
\hline \multirow{3}{*}{$\begin{array}{l}\text { Daily feed } \\
\text { consumption }\end{array}$} & 100.0 & 112.6 & 116.3 & 110.0 & 107.0 & 103.0 & 102.7 & \multirow{3}{*}{ NS } \\
\hline & \pm & \pm & \pm & \pm & \pm & \pm & \pm & \\
\hline & 5.43 & 5.43 & 6.44 & 4.64 & 7.66 & 5.82 & 4.77 & \\
\hline \multirow{6}{*}{$\begin{array}{l}\text { Feed conversion } \\
\text { ratio }(\mathrm{kg} \text { feed/ } \\
\mathrm{kg} \text { gain) } \\
\text { PI }(\%)\end{array}$} & 3.83 & 3.79 & 4.24 & 3.61 & 3.86 & 3.75 & 3.77 & \multirow{3}{*}{ NS } \\
\hline & \pm & \pm & \pm & \pm & \pm & \pm & \pm & \\
\hline & 0.7 & 0.9 & 0.6 & 0.7 & 0.8 & 0.8 & 0.7 & \\
\hline & $58.31^{\mathrm{c}}$ & $62.51^{\mathrm{b}}$ & $55.21^{\mathrm{a}}$ & $68.59^{c}$ & $61.14^{\mathrm{b}}$ & $66.30^{\mathrm{c}}$ & $59.41^{\mathrm{b}}$ & \multirow{3}{*}{0.05} \\
\hline & \pm & \pm & \pm & \pm & \pm & \pm & \pm & \\
\hline & 7.36 & 5.57 & 3.88 & 4.37 & 7.54 & 6.67 & 5.34 & \\
\hline Mortality \% & 0.0 & 0.0 & 0.0 & 0.0 & 0.0 & 0.0 & 0.0 & NS \\
\hline
\end{tabular}

*M, Moringa; C, Cassava; T, Tartofa at both levels 10 and $15 \%$ and $A H$, alfalfa hay (control).

$* a, b$ and $c$ Means in the same row with different superscripts differ significantly.

NS; not significant.

PI, performance index: percentage of final BW relative to feed conversion (North, 1981)

Musa (2008) reported almost similar values of total gain and ADG for growing NZW rabbits when they were fed diets containing parsley or basil wastes at two levels (10 or 20\%) replacing clover hay. However, El-Manylawi et al. (2005) reported that the final body weight and weight gain of growing rabbits fed diets containing 3, 6 or $9 \%$ of Geranium by-products were significantly $(\mathrm{P}<0.05)$ higher than the control group. Earlier study on growing pigs (Teodorovic et al., 1990) showed higher daily weight gain when thyme was added to pigs diets at $1-2 \mathrm{~kg} /$ ton diets than the control. Tesfaye et al. (2012) reported similar effect of Moringa oleifera on growth rate when fed to broiler chicks. Data in Table (5) present the average daily feed consumption of growing rabbits; total feed per rabbit during the 8-weeks experimental period was 5.77, 6.31, 6.51, 6.16, 5.99, 5.77 and 5.75 kg for AH, M10, M15, C10, C15, $\mathrm{T} 10$ and T15, respectively. The average feed consumption during the experimental period was fluctuated but did not reach the significant level. Earlier study (Musa, 2008) found that average daily feed consumption during the experimental period was $108.3,110.8,80.7,92.5,93.5,104.5$ and $108.5 \mathrm{~g}$ for the experimental groups of control, 10 and $20 \%$ parsley, 10 and $20 \%$ basil or 10 and $20 \%$ mixture of both wastes, respectively. The differences in feed intake may have been due to the chemical structure of $\mathrm{CF}$ of wastes hay. Abou-Ashour and Ahmed (1983) concluded that CF level and/or structure negatively affect the feed consumption of growing rabbits. Adegbola and Okonkwo (2002) studied the nutrient consumption of rabbits fed varying levels of cassava leaf meal. DMI (g/d) ranged from 44.24 to 66.85; LWG (g/d) from 8.43 to 21.36 and feed conversion ratio from 3.13 to 5.27. Differences were significant. Economic analysis showed that control diet was the least economical. Tesfaye et al. (2012) used a total of 300 day-old broiler chicks with average initial body weight of $42.32 \pm 1.53 \mathrm{~g}$. Chicks were randomly distributed into 15 pens each with 20 chicks, representing five feeding treatments. The treatments were 
inclusion of Moringa oleifera leaf meal (MOLM) at 0 (Control, T1), 5 (T2), 10 (T3), 15(T4) and 20\% (T5) levels of the total ration at the expense of soybean meal. The experiment lasted for 56 days, during which they found that total DM and total CP intakes for the birds in T5 were greater than other treatments. Mendieta-Araica et al. (2010) used moringa leaf meal as a protein source in diets given to six lactating dairy cows fed a basal Elephant grass diet. The intake of dry matter, organic matter, neutral detergent fiber and acid detergent fiber did not differ significantly between treatments. Akinyemi et al. (2010) studied the effect of inclusion level on nutrient intake of sheep fed Moringa oleifera as supplements to Panicum maximum a completely randomized design experiment using twenty rams with average initial weight of $16 \mathrm{~kg}$. There were five treatments $1-5$ with $0,25,50,75$ and $100 \%$ M. oleifera inclusion levels, respectively. M. oleifera had better nutrient profile with $29.68 \% \mathrm{CP}$ and $16.98 \% \mathrm{CF}$ contents than P. maximum with $9.17 \% \mathrm{CP}$ and $40.37 \% \mathrm{CF}$. Inclusion of M. oleifera as supplement to $P$. maximum in the diets significantly lowered $(\mathrm{P}<0.05) \mathrm{DM}$ intake especially at higher $(>50 \%)$ inclusion rates. Intakes of OM, EE and NFE were similar but $\mathrm{CP}$ intake increased while $\mathrm{CF}$ intake decreased $(\mathrm{P}<0.05)$ as inclusion level increases.

Feed conversion ( $\mathrm{kg}$ feed $/ \mathrm{kg}$ gain; Table 5) during the period of the study was not affected by the dietary treatments under which the experimental animals were kept. This may have been due to the equality of both feed intakes along with growth rate. Feed conversion ratio was 3.83, 3.79, 4.24, 3.61, 3.86, 3.75 and 3.77 for AH, M10, M15, C10, C15, T10 and T15, respectively. Musa (2008) found that improvements in weight gain occurred in rabbits fed parsley hay meal or its mixture with basil may have been due to the biological functions of the main components of the residual essential oil in the parsley and basil by-products (El-Shenawi, 1992; Abd El-Azeem, 1999; Awad, 2003 and El- Manylawi et al 2005). Bello and Abdulkarim (2015) used 20 cross-breed weaned rabbits to assess performance of growing rabbits fed cassava meal. Cassava meal was included at $0,25,50$ and $75 \%$ to replace maize in the diets (treatment 1-4, respectively. Rabbits were randomly allocated to four diets. The results showed a non-significant effect on all the performance parameters. The daily feed intake $(35-47 \mathrm{~g})$, daily weight gain (7.8-12.56 g) and feed conversion ratio (3.65-4.48) was not influenced by the dietary level of cassava meal. Oliveira et al. (2008) studied the performance of 144 New Zealand White rabbits from weaning to slaughtering ( 31 to $70 \mathrm{~d}$ of age) when fed with control or experimental cassava diets. A significantly lower feed intake $(\mathrm{P}=0.007)$ was observed for rabbits received cassava diet until weaning $(129$ vs. $138 \mathrm{~g} / \mathrm{d})$ resulting in a lower feed: gain ratio $(3.03$ vs. $3.22 ; \mathrm{P}<0.001)$ during the fattening period. The silage process improved significantly the feed: gain ratio (2.92 vs. 3.16 with non-ensiled cassava and 3.28 for the control) in relation with of a lower feed intake, but there was non-significant effect of silage processing on average rabbit growth rate and carcass characteristics.

In order to calculate the performance index percentage (PI) the average performance data (total gain, feed intake and feed conversion) were composited in one Table (Table 5). The results of performance index indicated that the highest PI value was significantly $(\mathrm{P}<0.05)$ recorded with group fed $\mathrm{C} 10$ diet $(68.59 \%)$ followed by those T10 (66.30\%), M10 (62.51\%), C15 (61.14\%), T15 (59.41\%). and AH (58.31\%) the least was recorded for M15 (55.21\%). Abousekken et al. (2007) reported that growing rabbits fed 36\% mixture of fennel hay and Marjoram hay recorded significantly $(\mathrm{P}<0.05)$ the best PI value, while, group fed dietary 36\% Marjoram hay only was the worst one. Musa (2008) came to the same conclusion that rabbits fed the mixture of medicinal plant wastes gave better PI than each one alone. In this respect, Rawiha (1994) stated that using mixtures of medicinal herbs was preferable than using each alone. Moreover, such improvements may have been attributed to the synergism between the main components of the tested plants included in these mixtures. In good agreement with the present results, Stephan (1980); Yousef et al. (1998); Yamani and Farghally. (1994) and Szendro et al. (1998) reported that poor growth performance of rabbits resulted mainly from the decrease in feed intake (with impaired feed conversion) which may lead to less protein biosynthesis and/or less fat deposition; leading to lower gain. The animals, when receiving less feed intake, will keep enough feed-energy as a maintenance requirement and consequently the remained net energy for growth may be decreased resulting in a reduction in daily gain of growing rabbits.

No mortality was recorded during the experimental period in rabbit group fed diet containing any of the experimental diets (Table 5). The results of mortality rate may indicate that all animals were in good health and the dietary treatments had no adverse effect of any kind. In general no literature relating mortality rates of rabbits to feeding wastes of medicinal plants was available.

Results given in Table (6) show the apparent digestion coefficients of nutrients (mean $\pm \mathrm{SE}$ ) as affected by the different experimental diets. 
Table (6): Apparent digestion coefficients of the experimental diets as affected by dietary treatments (Means $\pm \mathrm{SE}$ )

\begin{tabular}{lcccccccc}
\hline & \multicolumn{7}{c}{ The experimental diet } & \multirow{2}{*}{ Sig. } \\
\cline { 2 - 6 } Item & $\mathrm{AH}$ & $\mathrm{M} 10$ & $\mathrm{M} 15$ & $\mathrm{C} 10$ & $\mathrm{C} 15$ & $\mathrm{~T} 10$ & $\mathrm{~T} 15$ & \\
& $55.72^{\mathrm{a}}$ & $56.49^{\mathrm{a}}$ & $68.19^{\mathrm{bc}}$ & $67.64^{\mathrm{b}}$ & $72.50^{\mathrm{c}}$ & $66.58^{\mathrm{b}}$ & $75.78^{\mathrm{c}}$ & \\
& \pm & \pm & \pm & \pm & \pm & \pm & \pm & 0.05 \\
OM & 5.86 & 2.16 & 3.17 & 2.54 & 2.97 & 0.93 & 1.61 & \\
& $53.62^{\mathrm{a}}$ & $56.49^{\mathrm{a}}$ & $69.72^{\mathrm{b}}$ & $68.59^{\mathrm{b}}$ & $73.83^{\mathrm{c}}$ & $67.94^{\mathrm{b}}$ & $77.25^{\mathrm{c}}$ & \\
& \pm & \pm & \pm & \pm & \pm & \pm & \pm & 0.05 \\
$\mathrm{CP}$ & 5.43 & 2.94 & 2.70 & 2.45 & 2.16 & 0.71 & 1.81 & \\
& $63.58^{\mathrm{a}}$ & $66.24^{\mathrm{b}}$ & $74.05^{\mathrm{c}}$ & $72.29^{\mathrm{c}}$ & $77.65^{\mathrm{c}}$ & $74.53^{\mathrm{c}}$ & $81.46^{\mathrm{d}}$ & \\
& \pm & \pm & \pm & \pm & \pm & \pm & \pm & 0.05 \\
$\mathrm{CF}$ & 1.31 & 1.74 & 2.87 & 3.22 & 1.27 & 0.60 & 1.36 & \\
& $19.42^{\mathrm{a}}$ & $18.78^{\mathrm{a}}$ & $38.09^{\mathrm{c}}$ & $21.99^{\mathrm{b}}$ & $43.44^{\mathrm{c}}$ & $39.66^{\mathrm{c}}$ & $51.39^{\mathrm{d}}$ & \\
& \pm & \pm & \pm & \pm & \pm & \pm & \pm & 0.05 \\
$\mathrm{EE}$ & 3.64 & 6.48 & 7.55 & 5.36 & 4.63 & 3.09 & 2.32 & \\
& $64.30^{\mathrm{b}}$ & $66.99^{\mathrm{a}}$ & $78.87^{\mathrm{c}}$ & $84.50^{\mathrm{cd}}$ & $89.23^{\mathrm{d}}$ & $83.61^{\mathrm{cd}}$ & $82.41^{\mathrm{c}}$ & \\
& \pm & \pm & \pm & \pm & \pm & \pm & \pm & 0.05 \\
& 2.10 & 2.74 & 0.32 & 4.57 & 2.97 & 1.53 & 2.33 & \\
$\mathrm{NFE}$ & $62.67^{\mathrm{b}}$ & $55.45^{\mathrm{a}}$ & $74.88^{\mathrm{c}}$ & $74.51^{\mathrm{c}}$ & $76.79^{\mathrm{c}}$ & $70.07^{\mathrm{c}}$ & $80.29^{\mathrm{d}}$ & \\
& \pm & \pm & \pm & \pm & \pm & \pm & \pm & 0.05 \\
& 1.59 & 1.99 & 1.79 & 2.14 & 2.29 & 1.17 & 1.96 & \\
\hline
\end{tabular}

*M, Moringa; C, Cassava; T, Tartofa at both levels 10 and 15\%; AH, control.

* OM, organic matter; $C P$, crude protein; $C F$, crude fiber; EE, ether extract and NFE, nitrogen-free extract.

$a, b, c$ and $d$. Means in the same row with different superscripts differ significantly.

Apparent digestion coefficients of DM were 55.72, 56.49, 68.19, 67.64, 72.50, 66.58 and 75.78\% for the AH, M10, M15, C10, C15, T10 and T15 diets, respectively. Differences were statistically significant $(\mathrm{P}<0.05)$. Digestibility of OM followed the same as DM; the respective values of OM were 53.62, 56.49, 69.72, 68.59, 73.83, 67.94 and 77.25\%; differences were significant $(\mathrm{P}<0.05)$. Digestibility of $\mathrm{CP}$ for the $\mathrm{AH}, \mathrm{M} 10, \mathrm{M} 15, \mathrm{C} 10, \mathrm{C} 15, \mathrm{~T} 10$ and T15 diets was $63.58,66.24,74.05,72.29,77.65,74.53$ and $81.46 \%$, respectively. Differences were statistically significant $(\mathrm{P}<0.05)$. Digestion coefficient of $\mathrm{CF}$ was low for AH (19.42\%), M10 (18.78\%) and C10 (21.99\%); the highest was that for T15 (51.39\%). The other groups had intermediate values. The lowest digestibility of $\mathrm{EE}$ was recorded for $\mathrm{AH}(64.3 \%)$ and $\mathrm{M} 10$ $(66.99 \%)$; however, both cassava and tartofa led to a higher $(\mathrm{P}<0.05)$ digestibility at both levels used $(10$ and $15 \%$ ) ranging between 78.87 to $89.23 \%$. The digestibility of NFE was $62.67,55.45,74.88,74.51$, 76.79, 70.07 and $80.29 \%$ for the experimental group's AH, M10, M15, C10, C15, T10 and T15, respectively. Difference was significant $(\mathrm{P}<0.05)$. Musa $(2008)$ observed that increasing replacement level of parsley and/or basil from 10 to $20 \%$ improved digestion coefficients of CF. Apparent digestibility of $\mathrm{CF}$ increased from 30.39 up to $71.28 \%$. In general, the improvement in digestibility could be attributed to the improvements in digestive tract environment due to herbal content of biological constituents such as antioxidants (Ali et al., 2007). Also, it may be observed that the higher digestibility was relative to lower feed intake where the decreases in feed intake lead to an increase in digestibility of almost all nutrients. The lower feed intake generally decrease the digesta flow rate leading to more time for nutrients to expose to the digestive enzymes which will result in more efficient digestion. Baraghit $e t$ al. (1995) reported that digesta flow rate is negatively correlated with feed intake which would allow the nutrients to be available to the digestive enzymes for longer time. These means that the feed taken by rabbits was potentially digestible but due to the high flow rate in rabbits with more feed intake, feed may not be completely digested. Mendieta-Araica et al. (2010) studied the effect on milk yield, milk composition and ration digestibility of using moringa leaf meal. The treatments did not differ with regard to digestibility with the exception of CP digestibility. Akinyemi et al. (2010) studied the effect of inclusion level on digestibility of sheep fed Moringa oleifera. The best DM, OM, CP and NFE digestibility were obtained at $100 \%$ moringa inclusion while CF and EE digestibility were highest at 25 
$\%$ inclusion level which also gave similar DM and CP digestibility with $100 \%$ inclusion. Nouala et al. (2006) conducted a study to investigate the effect of various levels of Moringa oleifera supplementation on in vitro digestibility. fermentation and in vitro digestibility were significantly higher with Moringa oleifera compared to other treatments. Adegbola and Okonkwo (2002) reported that cassava leaf meal did not negatively affect the digestibility and growth rate of rabbits fed varying levels of cassava. Ersahince and Kara (2017) carried out a study to determine the nutrient composition and in vitro digestion parameters of Jerusalem artichoke (Helianthus tuberosus L.) herbage at different maturity stages (vegetative, early flowering, full flowering and early seeding) in horses and ruminants. With the plant maturation the following parameters decreased $(P<0.05)$ : CP, NFC, ash and TSP content in plant samples, and in vitro total gas and methane production, T-DMd, T-OMd, ME values and molarities of individual VFA's for both horses and ruminants. Consequently, Jerusalem artichoke herbage, especially at vegetative stage, has the potential to be used as quality forage in terms of high/moderate nutrient composition and satisfactory digestion values for both horses and ruminants.

The nutritive values of the experimental diets are presented in Table (7). The results indicated that rabbits fed diet containing tartofa at the level of $15 \%$ (T15) were significantly $(\mathrm{P}<0.01)$ higher in their digestible crude protein (DCP) being $13.8 \%$ than control diet (11.66\%) and M10 being (11.87\%). The other groups were intermediates ranging between 12.82 in $\mathrm{C} 10$ and $13.43 \%$ in $\mathrm{C} 15$.

The group fed dietary $15 \%$ cassava $(\mathrm{C} 15)$ recorded significantly $(\mathrm{P}<0.01)$ the best value of total digestible nutrients (TDN, 89.8\%) and digestible energy (DE, $3954 \mathrm{kcal} / \mathrm{kg}$ ). The least values were recorded for M10 (61.2\% TDN and $2693 \mathrm{kcal} / \mathrm{kg} \mathrm{DE})$. Nutritive values as TDN and DE were 67.4, 2967; 77.2, 3396; 79.7, 3505; 79.6, 3502; 85.3, 3754 for AH, M15, C10, T10 and T15, respectively. These results indicated that, using hay of such medicinal plants in growing rabbit diets causes improvement in the digestion coefficients and feeding values than alfalfa hay.

Table (7): Nutritive values of the experimental diets as affected by dietary treatments (Means \pm SE).

\begin{tabular}{ccccccccc}
\hline & \multicolumn{7}{c}{ Treatments } & Sig. \\
\cline { 2 - 7 } Item & $\mathrm{AH}$ & $\mathrm{M} 10$ & $\mathrm{M} 15$ & $\mathrm{C} 10$ & $\mathrm{C} 15$ & $\mathrm{~T} 10$ & $\mathrm{~T} 15$ & \\
& $11.66^{\mathrm{bc}}$ & $11.87^{\mathrm{ab}}$ & $12.91^{\mathrm{ab}}$ & $12.82^{\mathrm{ab}}$ & $13.43^{\mathrm{ab}}$ & $13.08^{\mathrm{c}}$ & $13.80^{\mathrm{a}}$ & \\
& \pm & \pm & \pm & \pm & \pm & \pm & \pm & 0.05 \\
& 0.53 & 0.59 & 0.94 & 1.71 & 0.54 & 0.67 & 0.15 & \\
TDN & $67.4^{\mathrm{a}}$ & $61.2^{\mathrm{ab}}$ & $77.2^{\mathrm{b}}$ & $79.7^{\mathrm{b}}$ & $89.8^{\mathrm{bc}}$ & $79.6^{\mathrm{b}}$ & $85.3^{\mathrm{c}}$ & \\
& \pm & \pm & \pm & \pm & \pm & \pm & \pm & 0.01 \\
& 2.08 & 2.01 & 2.42 & 2.05 & 1.88 & 0.65 & 1.51 & \\
$\mathrm{DE}$ & $2967^{\mathrm{a}}$ & $2693^{\mathrm{a}}$ & $3396^{\mathrm{b}}$ & $3505^{\mathrm{b}}$ & $3954^{\mathrm{bc}}$ & $3502^{\mathrm{b}}$ & $3754^{\mathrm{c}}$ & \\
& \pm & \pm & \pm & \pm & \pm & \pm & \pm & 0.01 \\
& 91.7 & 88 & 105 & 89 & 82,7 & 28.7 & 66.6 &
\end{tabular}

\footnotetext{
*M, Moringa; C, Cassava; T, Tartofa at both levels 10 and $15 \%$ and AH, alfalfa hay (control).

${ }^{*} D C P$, digestible crude protein $\%$.

$T D N$, total digestible nutrients \%.

DE, digestable energy $(k c a l / k g D M)=T D N \times 4.4$ according to Schneider and Flatt (1975)

$a, b$,and $c$. Means in the same row with different superscripts differ significantly.
}

Abousekken et al. (2007) and Musa (2008) concluded that by using dietary mixture of medicinal hay in growing rabbit diet the nutritive values of the experimental diets may be improved. These significant improvements in the digestion coefficients and nutritive values by medicinal wastes may be due to the effect of some flavonoids and essential oils which had beneficial effect for stimulation and activity of cecum fermentation (Ibrahim, 2005). Apparent digestibility of CF in this group was significantly higher than the other groups. In this concern, Aboul-Fotouh et al. (1999) found that the highest TDN, DE and DCP values obtained when sheep diets contained 5\% Cymbopogon herbage $+3 \%$ Eucalyptus globules than the other treatments. Yousef et al. (1998) reported that TDN and DCP for Nigella sativa cake 
showed reasonable estimates compared with clover hay.

Data of the nitrogen balance are presented in Table (8). Nitrogen intake followed the same pattern as the feed intake. Values of NI were 2.68, 2.87, 2.88, 2.78, 2.64, 2.58 and 2.48g/d for AH, M10, M15, $\mathrm{C} 10, \mathrm{C} 15, \mathrm{~T} 10$ and T15, respectively. Differences were significant $(\mathrm{P}<0.05)$. Nitrogen excreted $(\mathrm{g} / \mathrm{d})$ in feces $(\mathrm{FN})$ and in urine (UN) were 0.99 and $0.40 ; 0.98$ and $0.47 ; 0.75$ and $0.81 ; 0.78$ and $0.54 ; 0.61$ and $0.75 ; 0.65$ and $0.57 ; 0.47$ and 0.70 for the respective experimental treatments. Differences were significant $(\mathrm{P}<0.05)$. Data reveal that rabbits on diets M10 and $\mathrm{C} 10$ retained the most $(\mathrm{P}<0.05)$ nitrogen being 1.42 and $1.46 \mathrm{~g} / \mathrm{d}$ comparing to the least value of 1.28 and 1.29 for $\mathrm{C} 15$ and $\mathrm{AH}$. The other groups retained between 1.31 to $1.36 \mathrm{~g} / \mathrm{d}$. In general, replacing alfalfa hay with either one of the medicinal plant wastes increased nitrogen balance of growing rabbits. Table (8) presents the biological value (BV) of the dietary treatment; it was clear that $\mathrm{BV}$ reached the beak when rabbits were fed $\mathrm{AH}$ and the wastes of Moringa at $10 \%$.

Table (8): Nitrogen balance as affected by dietary treatments (Means \pm SE).

\begin{tabular}{lcccccccc}
\hline Item & \multicolumn{7}{c}{ Treatments } & \multirow{2}{*}{ Sig. } \\
\cline { 2 - 6 } & AH & M10 & M15 & C10 & C15 & T10 & T15 & \\
\hline NI(g/d) & $2.68^{\mathrm{b}}$ & $2.87^{\mathrm{c}}$ & $2.88^{\mathrm{c}}$ & $2.78^{\mathrm{b}}$ & $2.64^{\mathrm{b}}$ & $2.58^{\mathrm{a}}$ & $2.48^{\mathrm{a}}$ & 0.05 \\
& \pm & \pm & \pm & \pm & \pm & \pm & \pm & \\
& 0.029 & 0.028 & 0.066 & 0.067 & 0.032 & 0.059 & 0.011 & \\
$\mathrm{FN}(\mathrm{g} / \mathrm{d})$ & $0.99^{\mathrm{c}}$ & $0.98^{\mathrm{c}}$ & $0.75^{\mathrm{b}}$ & $0.78^{\mathrm{b}}$ & $0.61^{\mathrm{a}}$ & $0.65^{\mathrm{b}}$ & $0.47^{\mathrm{a}}$ & 0.05 \\
& \pm & \pm & \pm & \pm & \pm & \pm & \pm & \\
& 0.081 & 0.043 & 0.052 & 0.051 & 0.029 & 0.043 & 0.043 & \\
$\mathrm{UN}(\mathrm{g} / \mathrm{d})$ & $0.40^{\mathrm{a}}$ & $0.47^{\mathrm{a}}$ & $0.81^{\mathrm{c}}$ & $0.54^{\mathrm{a}}$ & $0.75^{\mathrm{c}}$ & $0.57^{\mathrm{b}}$ & $0.70^{\mathrm{c}}$ & 0.05 \\
& \pm & \pm & \pm & \pm & \pm & \pm & \pm & \\
& 0.135 & 0.194 & 0.096 & 0.045 & 0.066 & 0.077 & 0.083 & \\
$\mathrm{NB}(\mathrm{g} / \mathrm{d})$ & $1.29^{\mathrm{a}}$ & $1.42^{\mathrm{b}}$ & $1.32^{\mathrm{a}}$ & $1.46^{\mathrm{b}}$ & $1.28^{\mathrm{a}}$ & $1.36^{\mathrm{ab}}$ & $1.31^{\mathrm{a}}$ & 0.05 \\
& \pm & \pm & \pm & \pm & \pm & \pm & \pm & \\
$\mathrm{BV}(\%)$ & 0.104 & 0.117 & 0.081 & 0.102 & 0.064 & 0.080 & 0.074 & \\
& $76.30^{\mathrm{c}}$ & $75.1^{\mathrm{b}}$ & $62.1^{\mathrm{a}}$ & $73.0^{\mathrm{b}}$ & $63.05^{\mathrm{a}}$ & $70.4^{\mathrm{b}}$ & $65.2^{\mathrm{a}}$ & 0.05 \\
& \pm & \pm & \pm & \pm & \pm & \pm & \pm & \\
$\mathrm{EDG}(\mathrm{g})$ & 2.67 & 6.36 & 2.82 & 1.84 & 1.94 & 2.05 & 3.00 & \\
& $27.35^{\mathrm{a}}$ & $30.1^{\mathrm{b}}$ & $28.1^{\mathrm{a}}$ & $30.9^{\mathrm{b}}$ & $27.3^{\mathrm{a}}$ & $28.9^{\mathrm{b}}$ & $27.7^{\mathrm{a}}$ & 0.05 \\
& \pm & \pm & \pm & \pm & \pm & \pm & \pm & \\
$\mathrm{ADG}$ & 2.16 & 2.44 & 1.69 & 2.12 & 1.37 & 1.67 & 1.54 & \\
$(\mathrm{~g} / \mathrm{d})$ & 26.9 & 29.7 & 27.4 & 30.4 & 27.7 & 27.5 & 27.2 & $\mathrm{NS}$ \\
& \pm & \pm & \pm & \pm & \pm & \pm & \pm & \\
\hline & 1.25 & 0.81 & 0.45 & 1.84 & 1.01 & 0.99 & 1.24 & \\
\hline
\end{tabular}

${ }^{*} N I$, nitrogen intake; $F N$, fecal nitrogen; $U N$, urinary nitrogen; $N B$, nitrogen balance; $B V$, biological value; $E D G$, expected daily gain according to $N B$ data and $A D G$, actual average daily gain.

a, band c. Means in the same row with different superscripts differ significantly .

NS; not significant.

Biological values were $76.3,75.1,62.1,73.0,63.1,70.4$ and $65.2 \%$ for AH, M10, M15, C10, C15, $\mathrm{T} 10$ and $\mathrm{T} 15$, respectively. Differences were significant $(\mathrm{P}<0.05)$. These results indicating that replacing alfalfa hay with medicinal plants wastes decreased BV by 1.57 (M10) to 18.61 (M15) leading to a decline in protein utilization with growing rabbits. Nitrogen balance results were used to calculate the expected daily gain (Table 8). The EDG was almost equal to that of the actual ADG; it is recommended that NB data could be accurately used to calculate average daily gain. Musa (2008) determined the biological value of the dietary protein from medicinal plant wastes (parsley, PHM and/or basil, BHM). It was significantly $(\mathrm{P}<0.01)$ higher for groups of rabbits fed the wastes at the lower level $(10 \%)$ especially when they were used as mixture than each one alone. Rabbits fed dietary 20\% of PHM and BHM mixture recorded significantly $(\mathrm{P}<0.05)$ the best values of $\mathrm{BV}$ compared to the other experimental diets or the control group. These results indicated that, using hay mixtures of such medicinal plants in growing rabbit diets causes improvement in digestion coefficients and feeding values more than using each alone. 
El-Manylawi et al. (2005) illustrated that the nitrogen balance for rabbits fed on diets containing Geranium by-product at 6 or $9 \%$ increased significantly $(\mathrm{P}<0.05)$ compared with the control group while, the difference did not significant between other groups. Musa (2008) reported that NB took the same trend as the average daily gain; therefore, he calculated the relationship between NB and ADG. Regression coefficient was positively and highly significant $\left(\mathrm{r}^{2}=0.78\right)$ accordingly he found that expected ADG followed the same pattern as the actual ADG using the NB values obtained in his study. He recommended that data of NB could be used to determine the expected ADG of rabbits. Working with sheep, Akinyemi et al. (2010) studied the effect of inclusion level of Moringa oleifera hay and found that $\mathrm{N}$ balance and retention were best under $25 \% \mathrm{M}$. oleifera and least under $75 \% \mathrm{M}$. oleifera. Adegun et al. (2011) came to the same conclusion.

\section{REFERENCES}

Abd EI-Baki, S. M ; E. A., Hassona; H. M. Ghanem, H. M. Yousef; A.A. Zaki; R.I. Moawd and S. A. Ebrahem (2001). Clays in animal nutrition. 7. Effect of feeding ensiled sulphuric acid-urcataflatreatedrice straw by crossbred Friesian bull calves on digestibility, growth performance and some physiological parameters. Egypt. J. Nutr. and Feeds. 4(1): 1-9.

Abd El-Azeem, S. N. (1999). The use of some medicinal plants in ruminant nutrition, $\mathrm{Ph} \mathrm{D}$. Thesis, Faculty of Agriculture, Fayoum, Cairo University.

Abou Ashour, A. M. and B . M. Ahmed (1983). Carcass and meat characteristics of Baladi rabbits fed different dietary fiber levels. Minufiya, J. Agric. Res.7:157-165.

Aboul-Fotouh, G. E; S. M. Allam; E. Shehata and S. N. Abd EI-Azeem (1999). Effect of some medicinal plants as feed additives on performance of growing sheep. Egyp. J. Nutr. and Feeds, 2 (2):79-87.

Abousekken, M. S. M; A. A. Fahmy and S. Z. S. Ahmed (2007). Performance of growing rabbits fed different levels of Fennel and Marjoram by- products and their mixture under desert environmental conditions. 9th Internat. Conf. Nutr. and Feeds. 12-15 Nov., Luxor, Egypt.

Adegbola T. A. and J. C. Okonkwo (2002). Nutrient intake, digestibility and growth rate of rabbits fed varying levels of cassava leaf meal. Nig. J. Anim. Prod. 29(1):21-26.

Adegun M.K; P.A. Aye and F.A.S. Dairo (2011). Evaluation of Moringa oleifera, Gliricidia sepium and Leucaena leucocephala - based multinutrient blocks as feed supplements for sheep in South Western Nigeria. Agric. and Biol. J. of North America .

Agricultural Economics (2006). Central administration, Agricultural Economics. Area, yield and production of medical, aromatic and flower plant. Economic Affairs Sector, Ministry of Agriculture, ARE.

Akinyemi, A; J. Fadiyimu; A. Alokanl and N. F. Adebowale (2010). Digestibility, Nitrogen balance and haematological profile of West African dwarf sheep fed dietary levels of Moringa oleifera as supplement to Panicum maximum. J. of American Science, 6(10):634-643 .

Ali, M. N; M. S. Hassan and F. A. Abd El-Ghany (2007). Effect of strain, type of natural antioxidant and sulphate ion on productive, physiological and hatching performance of native laying hens. Internat. J. Poultry Sci., 6: 539-554.

Al-Shanti, H. (2003). Effect of feeding olive cake on growth performance, nutrients digestibility, carcass traits and blood constituents of growing rabbits. Egyp. J. Rabbit Sci., 13: 103116.

AOAC (1990). Official Methods of Analysis (15th Ed). Association of Official Analytical Chemists. Washington, D.C., U.S.A.

Awad, Y. M. M. (2003). Studies on the utilization of some medicinal and aromatic plants processing wastes in rabbit feeding. M.S. Thesis, Envir. Studies and Res. Inst., Ain Shams University.

Baraghit G. A; B. M. Ahmed; A. M. Shehata and H. T. Taie (1995). Effect of clover intakes by sheep and goats on digestion kinetics. $5^{\text {th }}$ Scientific Conf. Anim. Nutr. Ismailia, Egypt. 
Bello. K.M. and Z. Adbulkarim (2015). Performance of weaner rabbits fed dietary levels of cassava root meal. Res. J. Anim. Sci. 9(1):1-3.

Cheeke, P. R. (1987). Rabbit Feeding and Nutrition. Academic Press.

Cieślik, E; A. Gębusia; A. Florkiewicz; B. Mickowska (2011) The content of protein and of amino acids in Jerusalem artichoke tubers (Helianthus tuberosus 1.) of red variety rote zonenkugel. Acta Sci. Pol., Technol. Aliment. 10(4), 433-441 .

Daadar, A. H. and T. S. T. Seleem (1999). Recent trends in rabbit Production. Proc. of 1st Inter. Conf. on Indigenous Versus Acclimatized Rabbits. PP. 23. El-Arish, Egypt.

Duncan, D.B. (1955). Multiple Range and Multiple F-test. Biometrics, 11:1-42.

El-Manylawi, M. A; M. R. M. Ibrahim; F. Ahmed and W. A. Salama (2005). Performance of growing rabbits fed diets containing Geranium and spearmint by-products. Egyp. J. Rabbit Sci., 15(1) : 13-26.

El-Manylawi, M. A; Y. I. El-Talty; N. Y. Abdel-Malak and H. A. Abdel- Magied (2003). Productive and metabolic traits of growing Baladi rabbits fed diets supplemented with medicinal and aromatic plants. Egyp. J. Nutr. and Feeds, 6 (special Issue):277-295.

El-Shenawi, A. (1992). Medicate by Herbal. Textbook, El-Eman Library, EL-Mansoura, Egypt.

Ersahince, A. C. and K. Kara (2017). Nutrient composition and in vitro digestion parameters of Jerusalem artichoke (Helianthus tuberosus L.) herbage at different maturity stages in horse and ruminant. J. of Anim. and Feed Sci , 26, 213-225.

FAO (1987). Rabbit Production. The 12th Session of the FAO.

Fritz, Z; A.,Schleicher and S. Kinal (1993). Effect of substituting milfoil, St. Jonswort and lovage for antibiotics on chicken performance and meat quality. J. Anim. and Feed Sci. 2(4), 189-195.

Fritz, Z; A. Schleicher; S. Kinal; L. Jarosz. and F. Majdanski (1992). Substitution of antibiotics by herbs in feed mixtures for broiler chicken. Roczniki-Noukowe, Zootechniki, MonografieiRozprawy, No. 31, 314-325.

Galal, E. S. E. and M. H. Khalil (1994). Development of rabbit industry in Egypt .Proc. of the 1st Inter. Conf. on Rabbit Prod. In Hot Climatic. P.P. 43, Cairo, Egypt.

Ibrahim, Sh. A. M. (2005). Effect of some medicinal plants as feed additives on growth and some metabolic changes in rabbits. Egyp. J. Nutr. and Feeds, 8: 207-219.

Mendieta-Araica, B; R. Sparndly; N. Reyes-Sanchez and E. Sparndly (2010). Moringa (Moringa oleifera) leaf meal as a source of protein in locally produced concentrates for dairy cows fed low protein diets in tropical areas. J. of American Sci . ;6 (10) .

Musa, A. M. (2008). The nutritive value of some common plants growing in the arid area. M.Sc. Thesis, Faculty of Agriculture, Minoufiya University.

Noland, P. R. (1965). Reports prepared for AID, Guatemala, A. (Mimeograph document). AID. Washington, D.C.

North, M. O. (1981). Commercial Chicken Production. Manual $2^{\text {nd }}$ Edition., ANI publishing Company ING, USA.

Nouala, F S; O. O. Akinbamijo; A. Adewumi; E. Hoffman; S. Muetzel and K. Becker (2006). The influence of Moringa oleifera leaves as substitute to conventional concentrate on the in vitro gas production and digestibility of groundnut hay. Livestock Research for Rural Development ,18 (9).

NRC (1977) National Research Council. Nutrient Requirements of Rabbits. Washington, DC.,

U S A.

Ogbe, A.O. and J.P. Affiku (2011). Proximate study, mineral and anti-nutrient composition of Moringa oleifera leaves harvested from Lafia, Nigeria: potential benefits in poultry nutrition and health. J. Micro Biotech . Food Sci. 1: 296-308 . 
Oliveira A. F. G; C. Maria; B. G. Scapinello; C. C. Jobim; C. Monteiro ; L. Furuta; W. M. Ferreira (2009). Use of simplify diet with cassava by- products for rabbits. Nutrition and Digestive Physiology.

Radwan, M. S. M. and E. F. Khalil (2002). Nutritional evaluation of fennel hay inclusion in rabbit diets. Egyp. J. Rabbit Sci., 12 : 85-94.

Rawiha, A. (1994). Medicate by herbal . Text book . Dar El-Kalem, Lebanon.

Schneider, B. and W. Flatt (1975). The evaluation of feeds through digestibility experiments. The University of Georgia Press; Athens. USA: p. 161-167.

Shqueir, A. and H. Qwasmi (1994).Utilization of olive by-product in livestock rations. Bethlehem Univ. J., $8: 45-54$.

Singh, B. and A. L. Taparia (1992). Effect of ammoniation of hill grasses on nutrient utilization by crossbred heifers. India J. Anim. Nutr. 9:1, 47-51.

SPSS (1997). (Statistical Package for Social Science) program version 13:0.

Stephan, E. (1980). The influence of environmental temperature on meat rabbits of different breeds. 2nd World Rabbit Congress, Cunicola, Barcelona. Spain, Vol. 1: 399-409.

Szendro, Z. S; Z. Papp and K. Kustos (1998). Effect of environmental temperature and restricted feeding on production of rabbit does.. 2nd International Conference on Rbbit Production in Hot Climates Adana, Turkey, 7-9 Sept . 1998.

Teodorovic, M., A. Sreckovic, J. Tot, F. KaJari, and L. Dragic. (1990). Efficacy of fito-diaro-stop in treating and preventing diarrhoea in piglets. Veterinarski-Glasnik, 44 (8):681-687.

Tesfaye, E; G; Animut, M. Urge, and T. Dessie. (2012). Effect of Replacing Moringa Oleifera Leaf Meal for Soybean Meal in Broiler Ration. Global Journal of Science Frontier Research Agriculture \& Biology.V (12):5. 2012.

Yamani ,K.A. and H.M. Farghally (1994). Adaptability of rabbits to the hot climate.First Intrnational Conference on Rabbit Production in Hot Climates., Cairo , Egypt. 6-8 Sept. 1994. P: 65-69.

Yousef, M. M; A. M., Abdiene; R. M. Kattab and S. A. Darwish (1998). Effect of feeding Nigella sativa cake on productive. Egyp. J. Nutri. and Feeds, 1:73-85

Zaza, G. H. M. (2004). Presentation on agricultural residues expert consultation on the utilization of agricultural residues. Workshop organized by FAO, Cairo, Egypt. 6-8 June.

Zaza, G. H. M. (2005). Effect of incorporation of biologically treated sugar beet pulp as a nonconventional feedstuff in the diet of growing rabbits. Proc. 4th Intern. Conf. Rabbits Prod. in Hot Climates, Sharm El-Sheik, Egypt, 267-274. 


\title{
تأثير بعض متبقيات النباتات الطبية على أداء الأرانب والهضم وميزان النيتروجين
}

\author{
كمـال محمد عبد الرحمن1 و بركات محمد أحمد1 و محمود سعد أبوسكين2 و أسـامة أبو العز نايل1 و أحمد محمد زكى

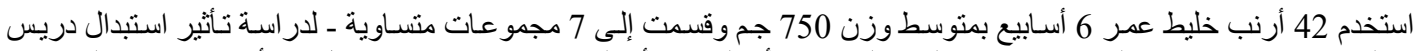

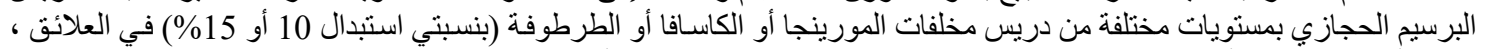

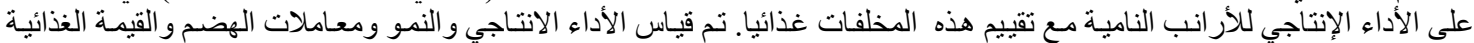

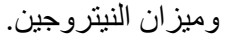

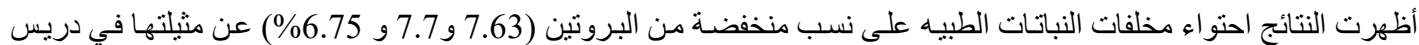

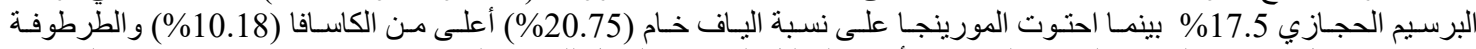

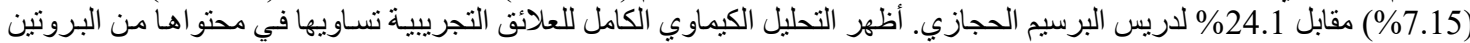

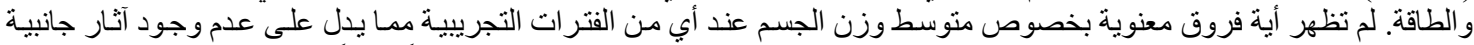

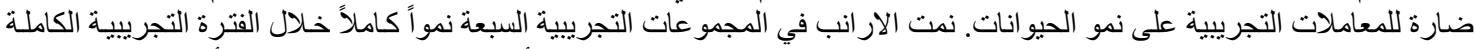

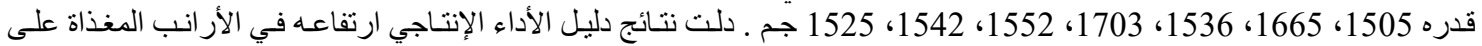

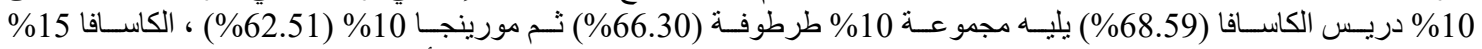

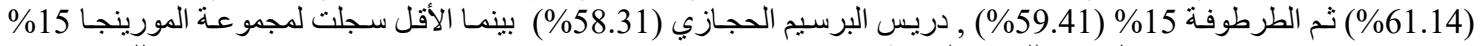

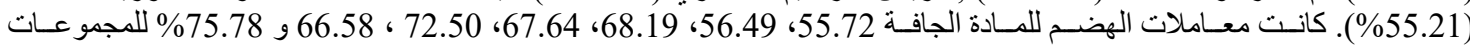

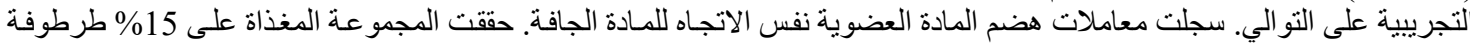

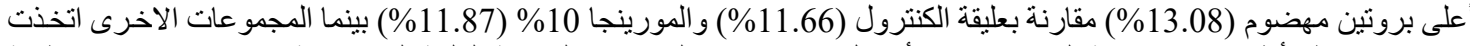

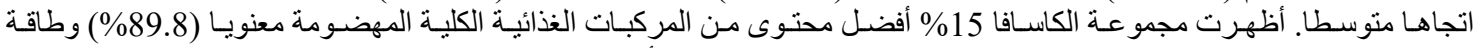

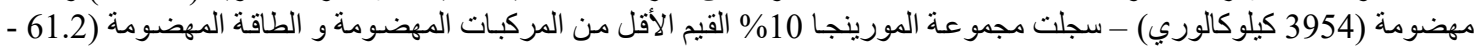

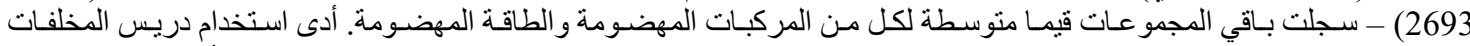

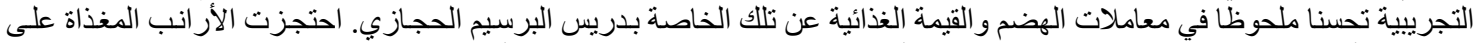

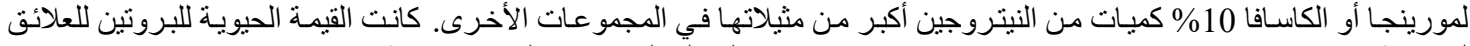

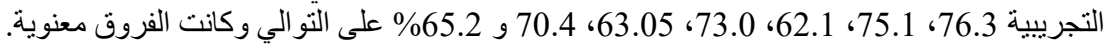

